\title{
Pengembangan Kebijakan Pertanian
}

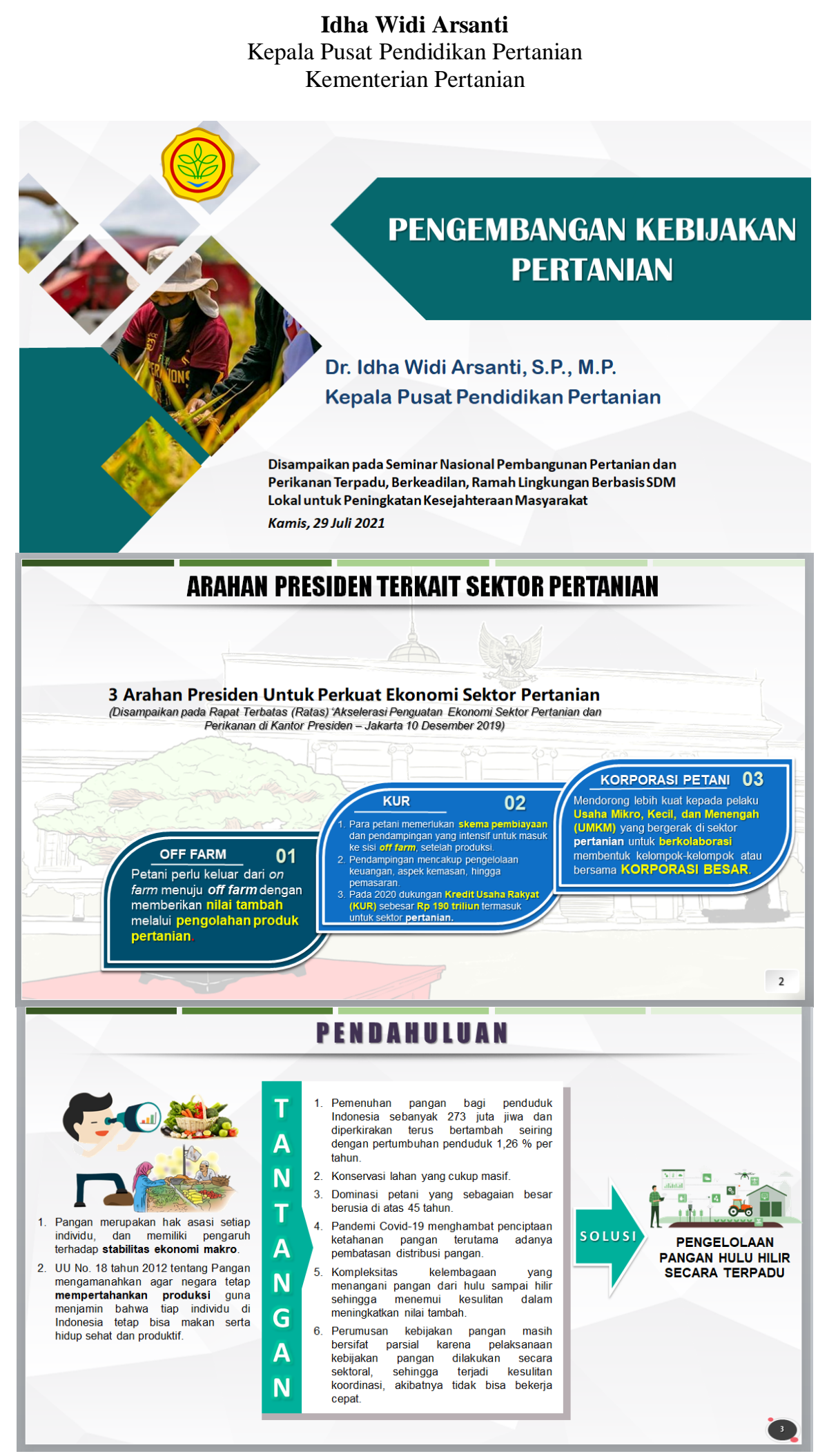




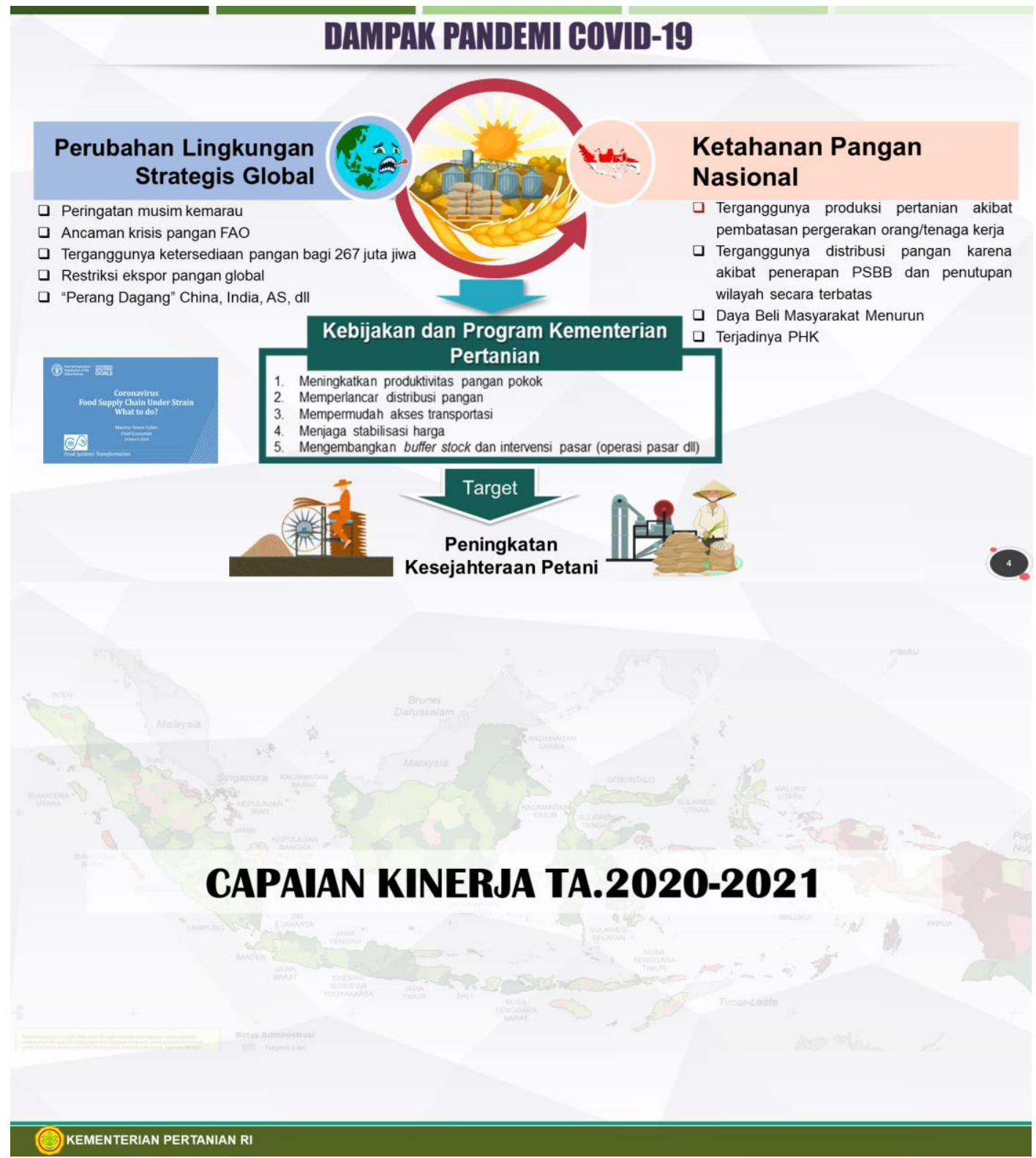

\section{REALISASI KEGIATAN UTAMA KEMENTAN TA 2020}

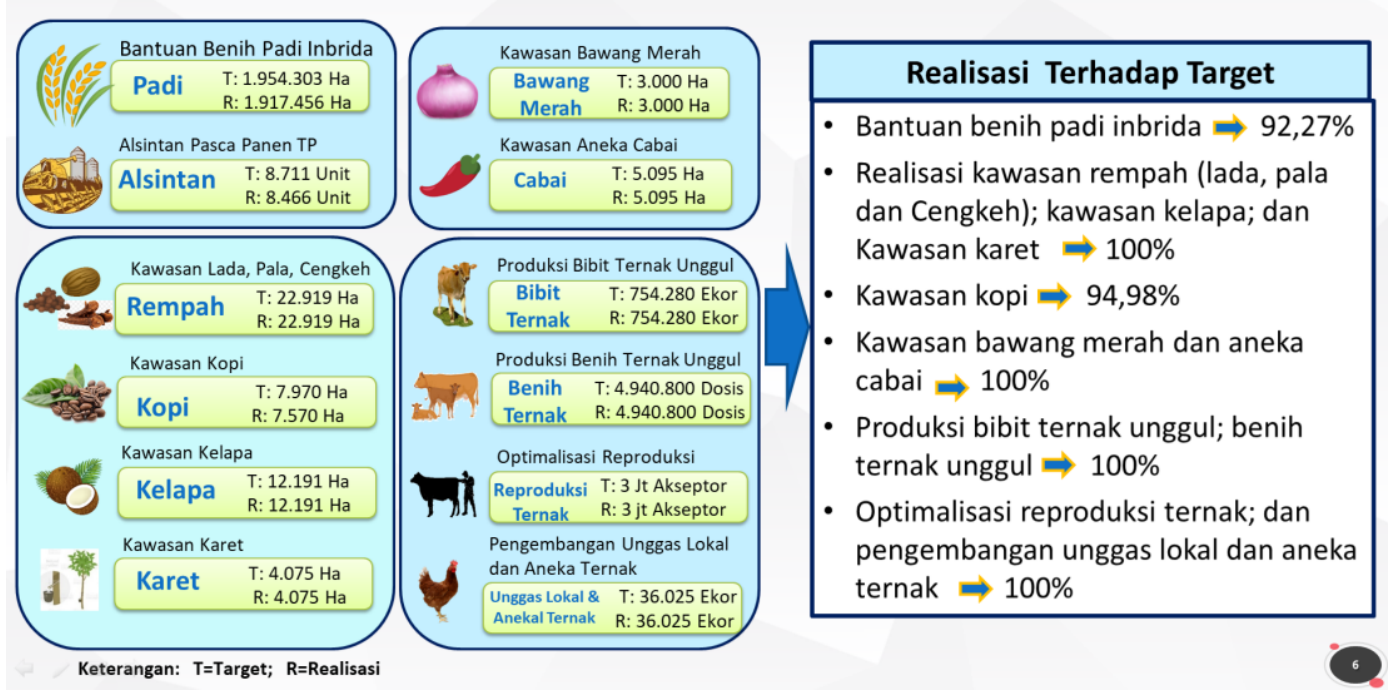

Proceedings homepage: https://conferenceproceedings.ump.ac.id/index.php/pspfs/issue/view/9 


\section{PERTUMBUHAN PDB MENURUT LAPANGAN USAHA}

TRIWULAN-II 2020 [Q-to-Q] : -4,19\%

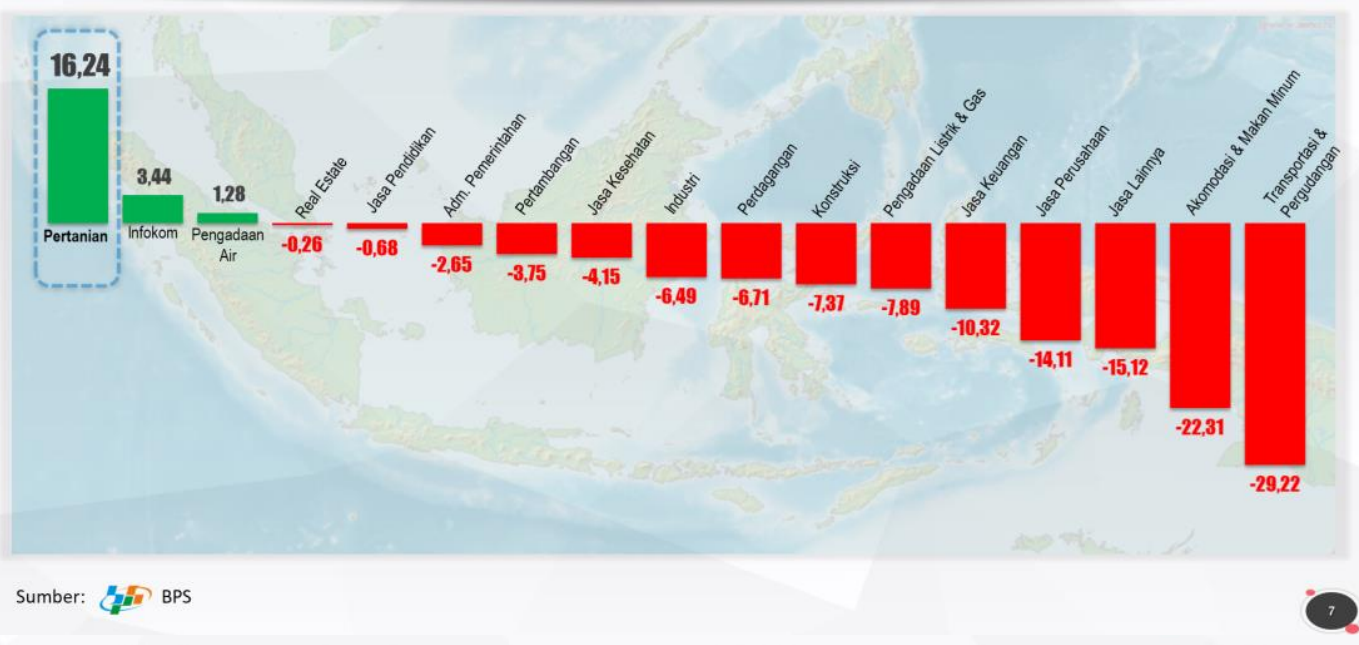

EKONOMI INDONESIA TRIWULAN-III 2020 TUMBUH [Y-on-Y] :-3,45\%

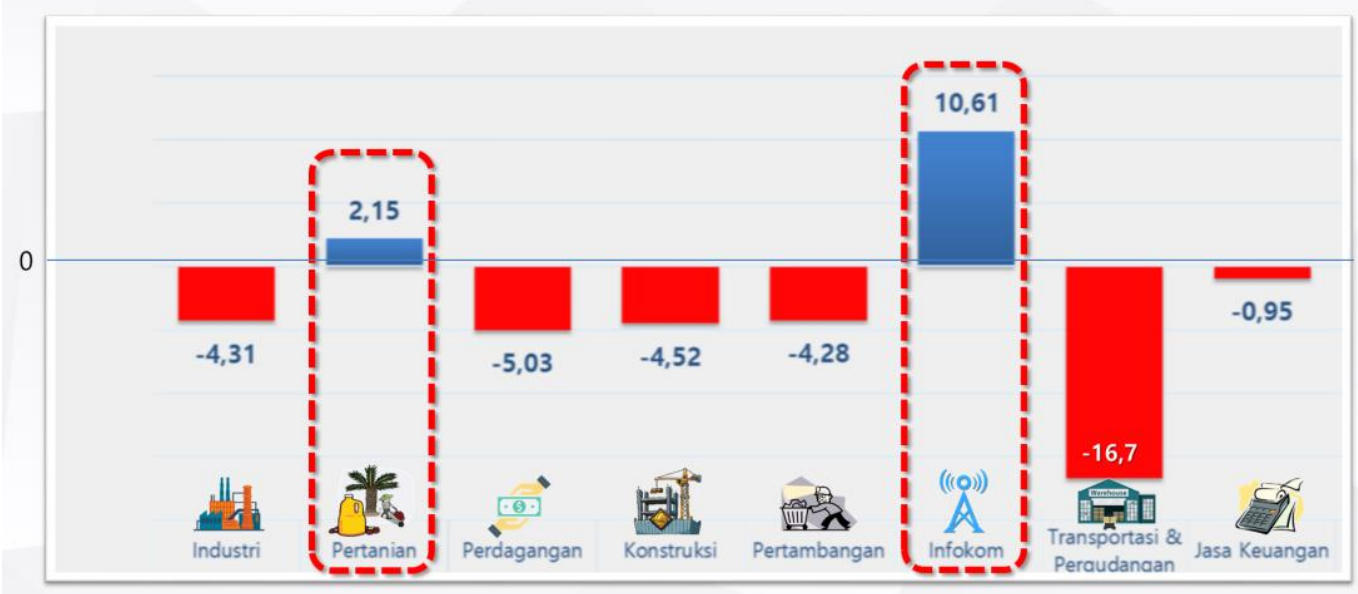

Sumber: $B$ BPS

\section{PERTUMBUHAN PDB MENURUT LAPANGAN USAHA}

TRIWULAN-II 2020 [Y-on-Y] : -2,19\%

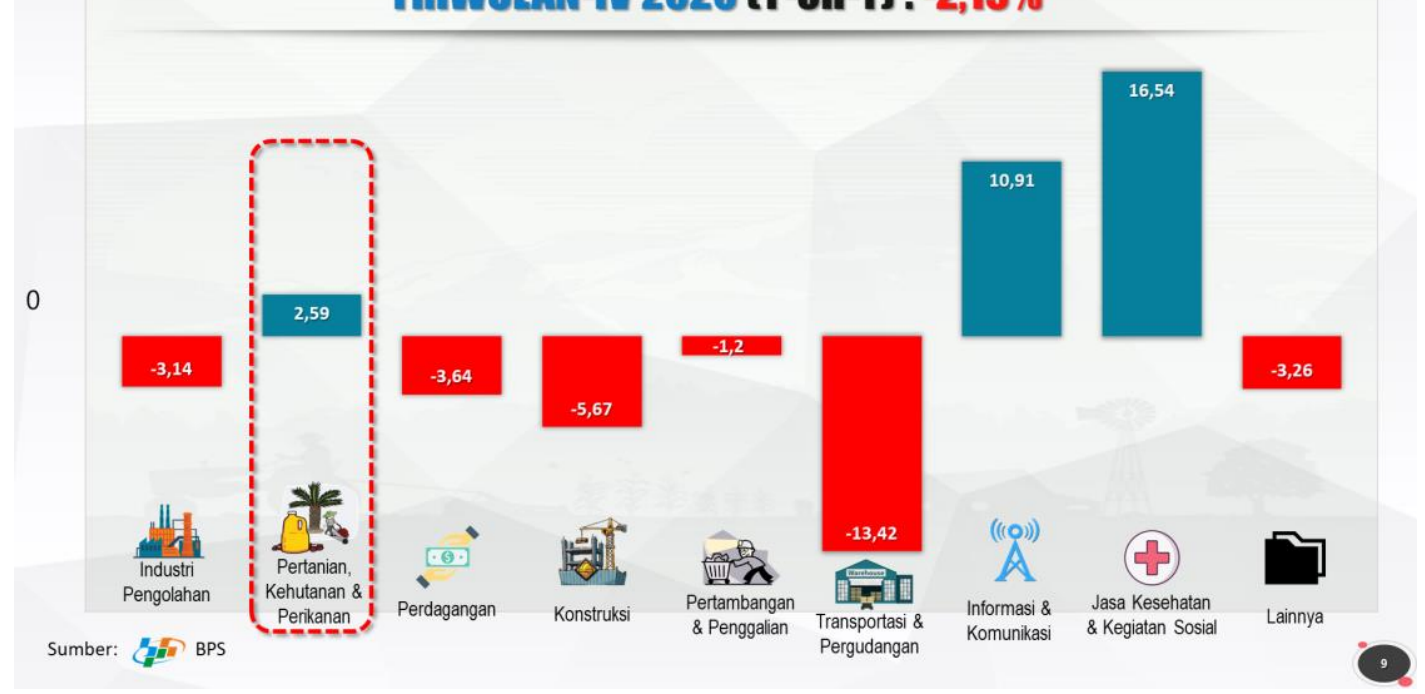




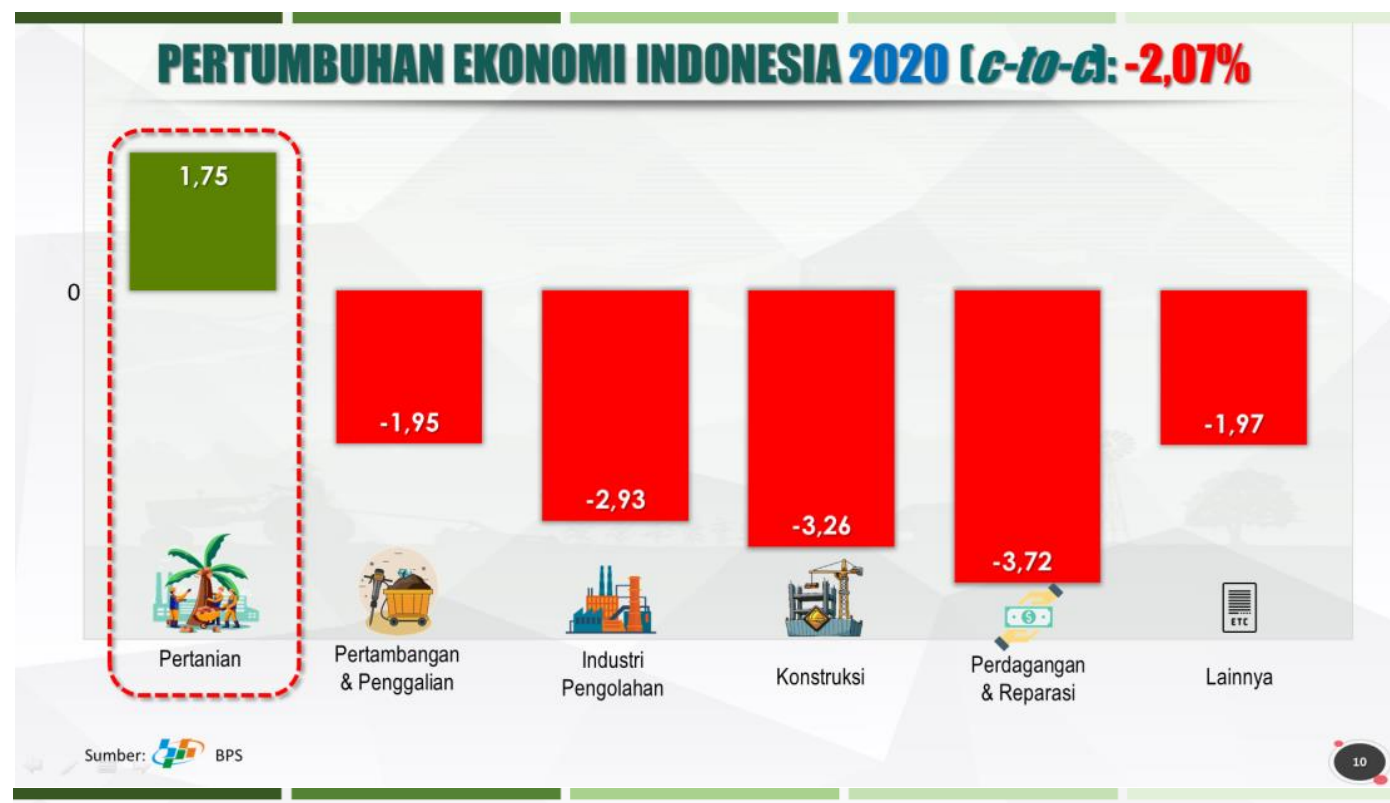

MILAI EKSPOR PERTANIAN JANUARI-DESEMBER 2019-2020 [Rp T]

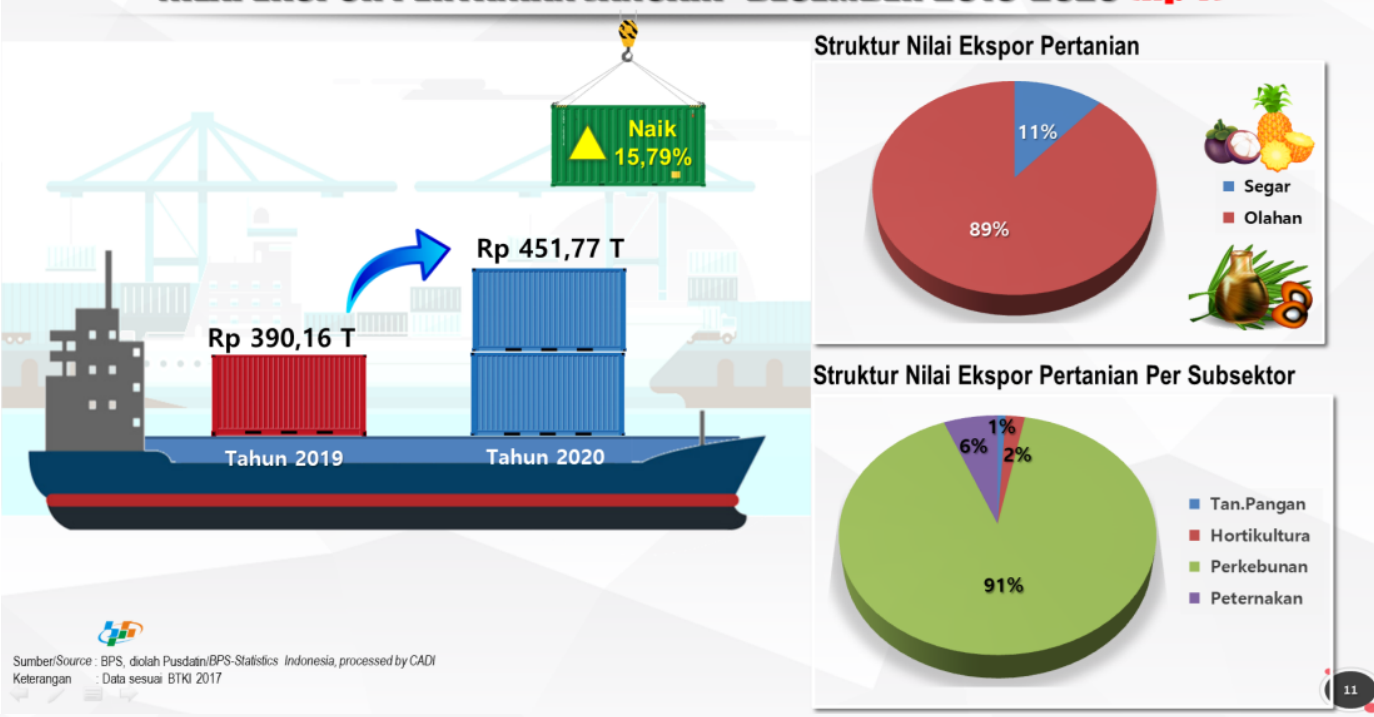

REALISASI KEGIATAN UTAMA KEMENTAN TA 2021
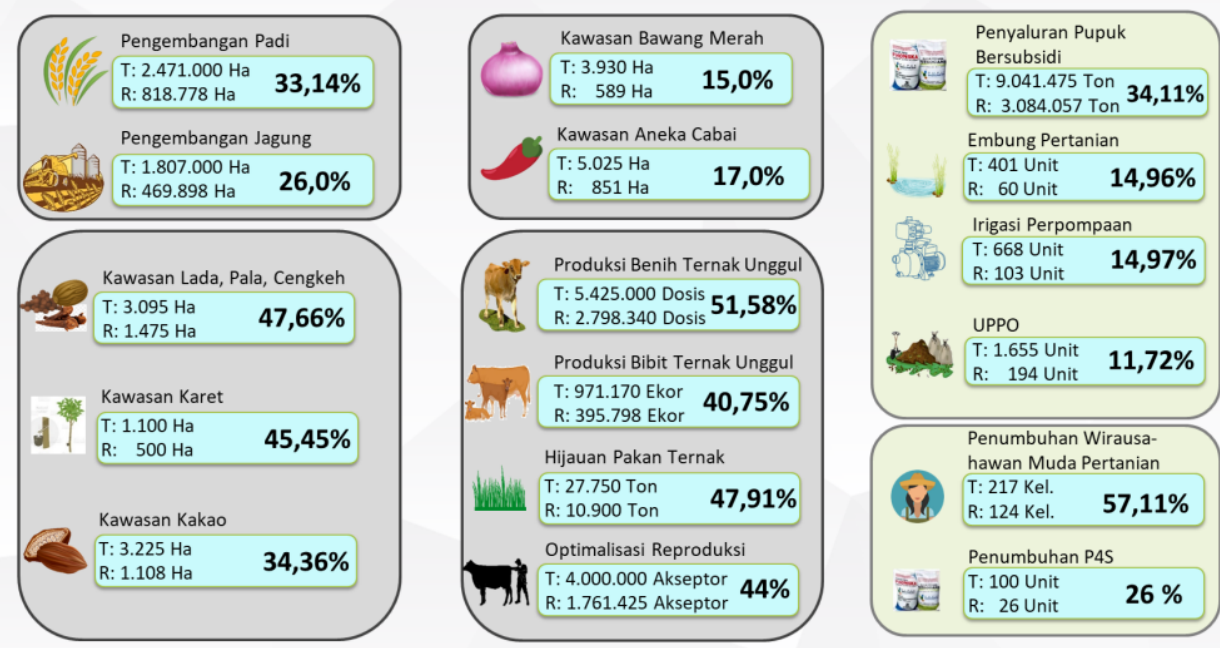

Keterangan: T=Target; R=Realisasi 


\section{PERTUMBUHAN EKONOMI TRIWULAN I 2021 [Y-on-Y): -0,74\%}

8,72

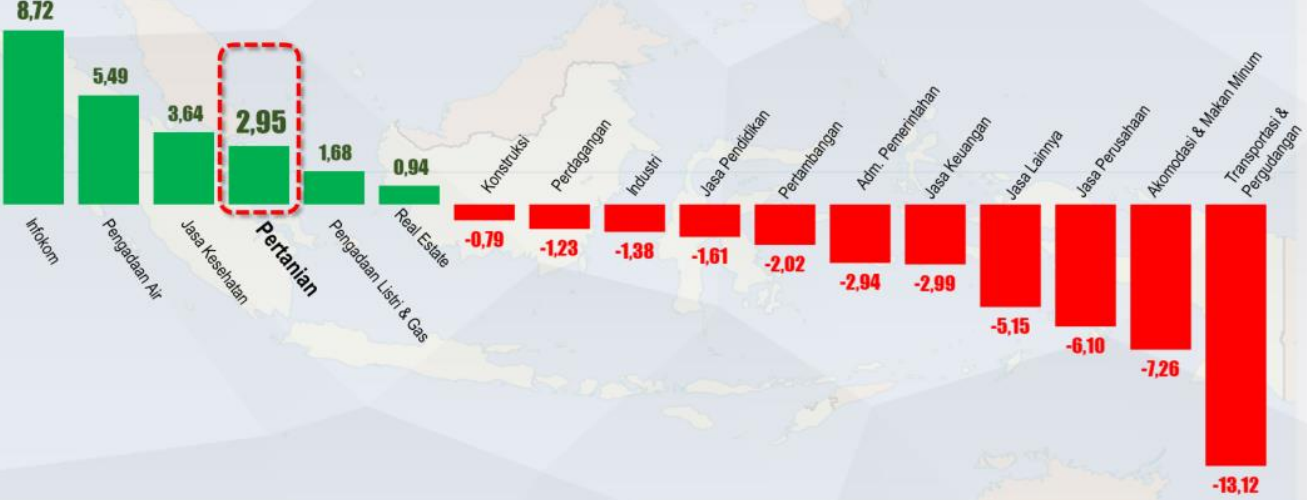

Sumber:

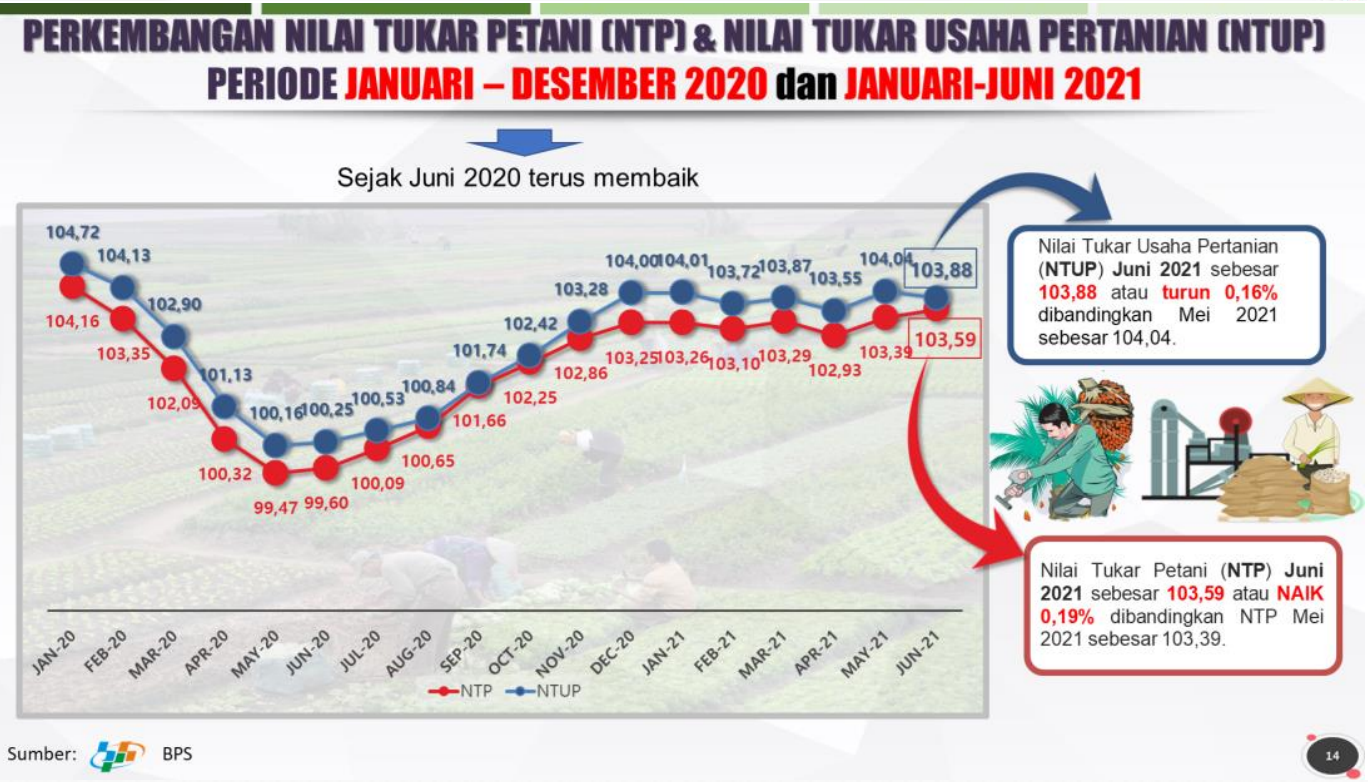

EKSPOR PERTANIAN (SEGAR, OLAHAN) JAN-JUN 2020 \& JAN-JUN 2021

(Rp. Triliun)

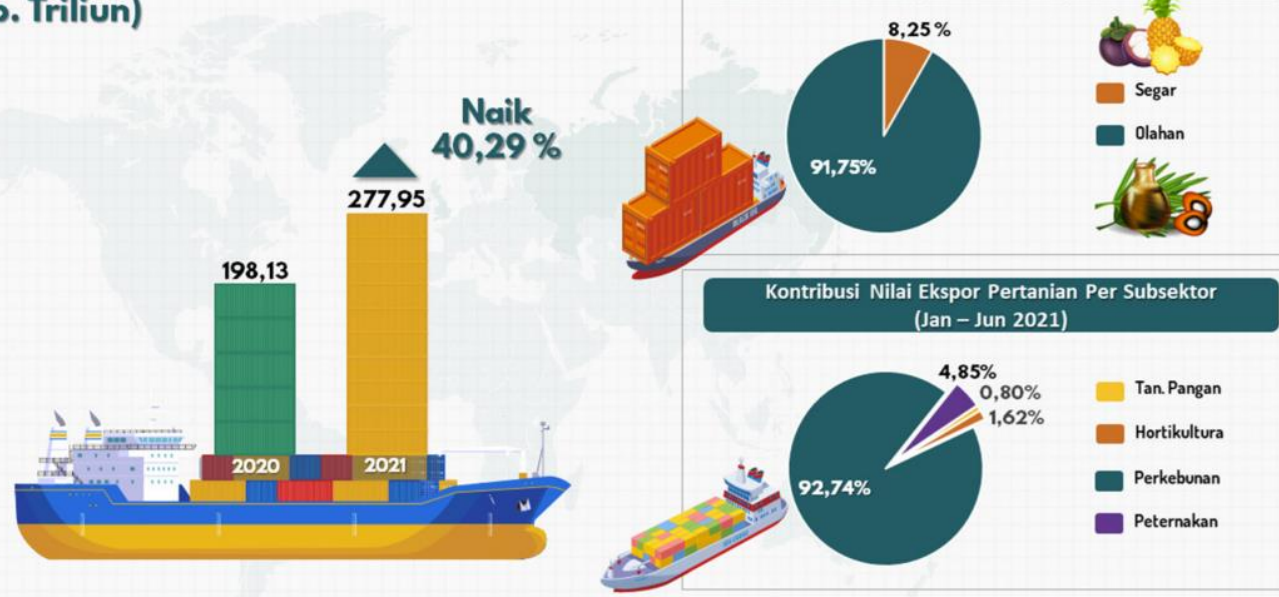




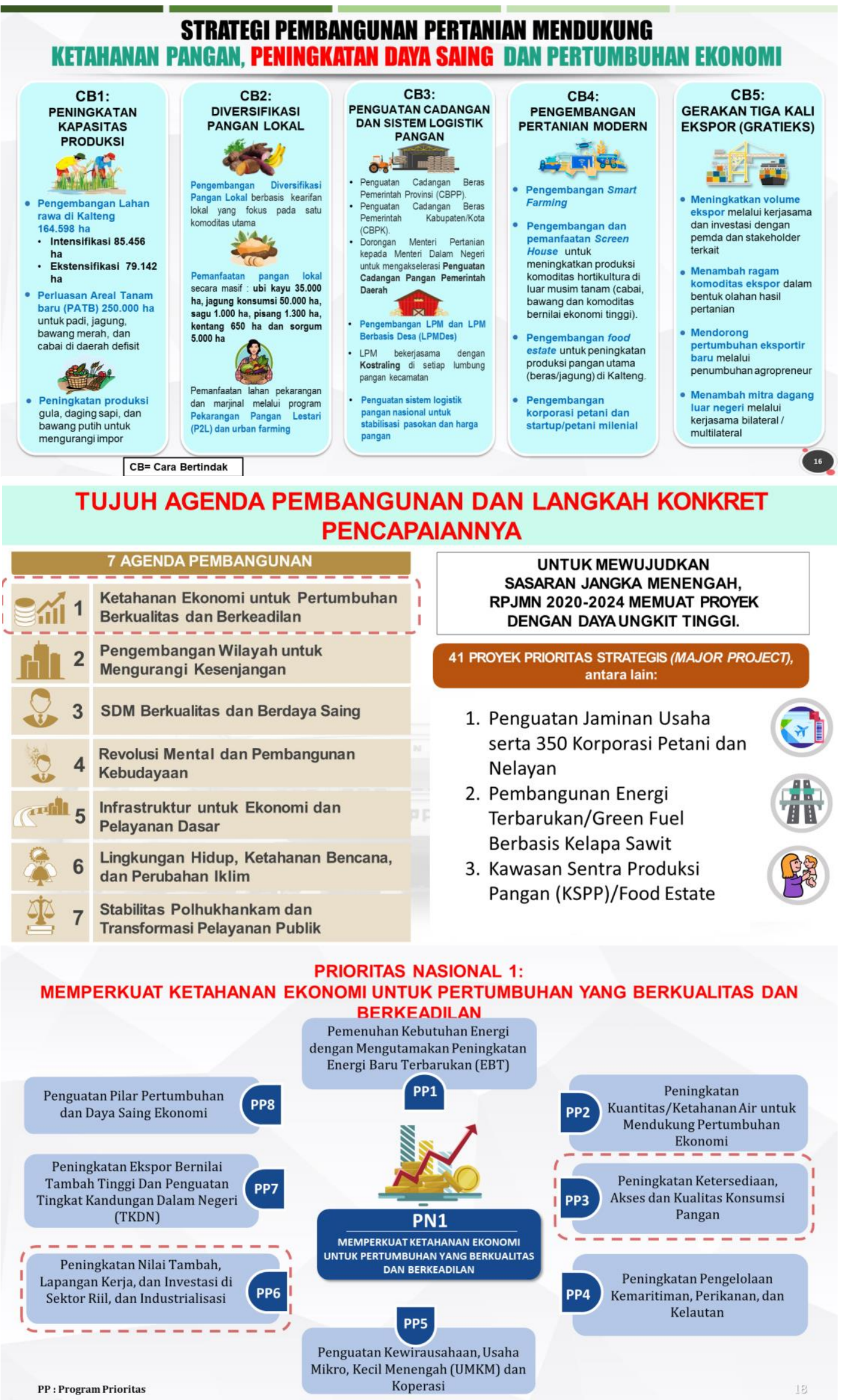




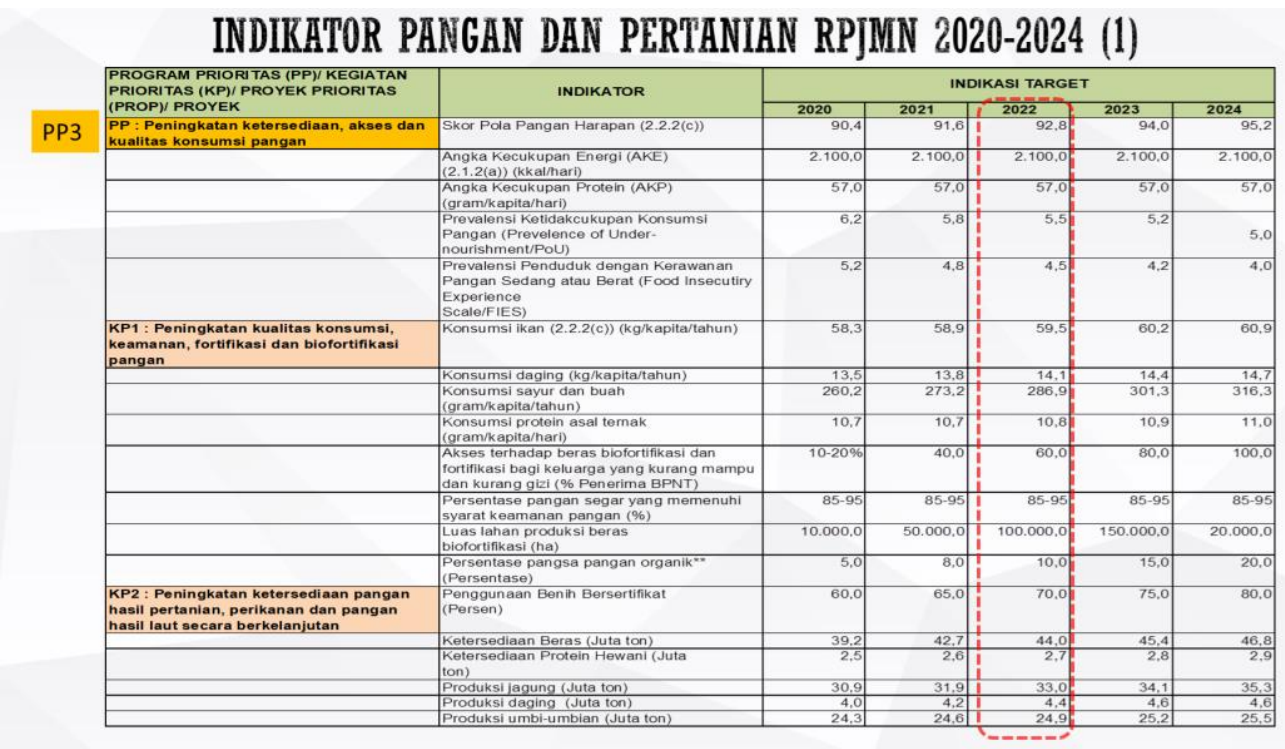

INDIKATOR PANGAN DAN PERTANIAN RPJMN 2020-2024 (2)

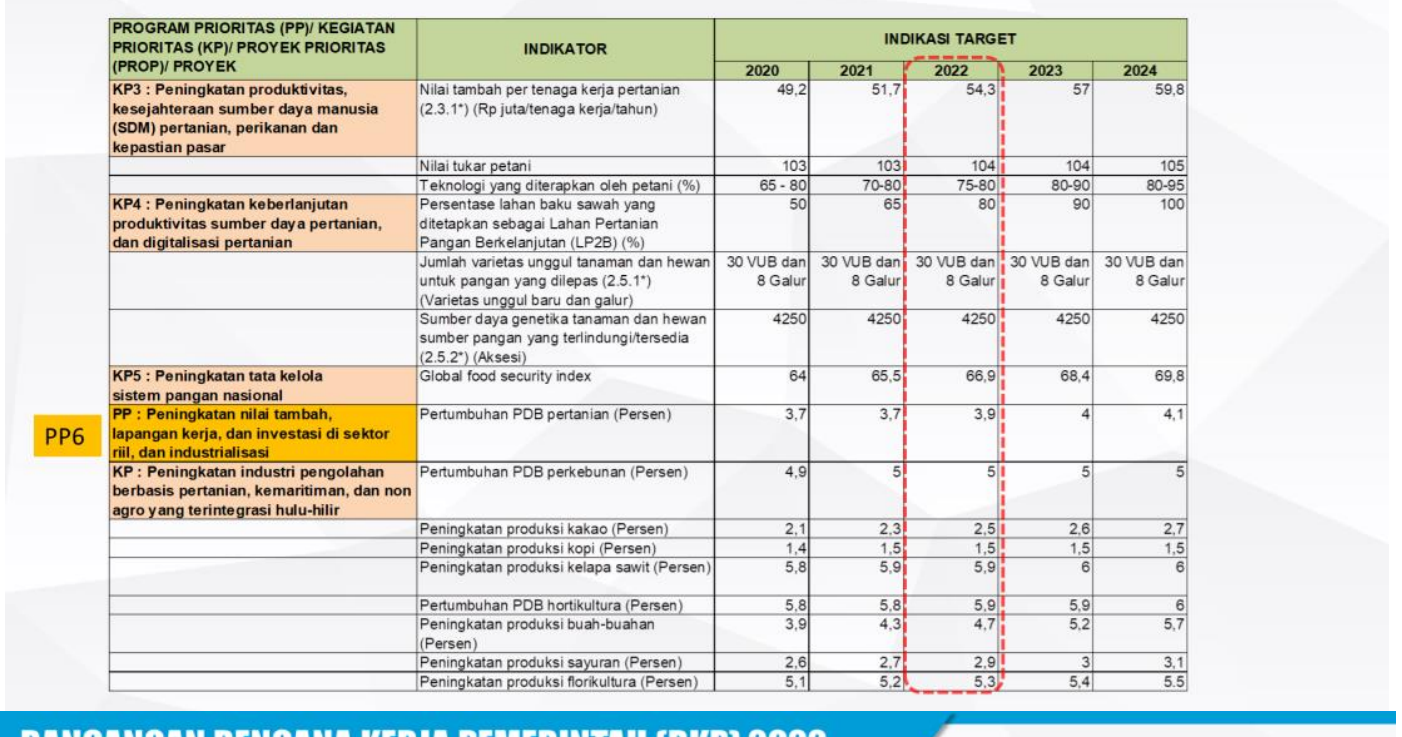

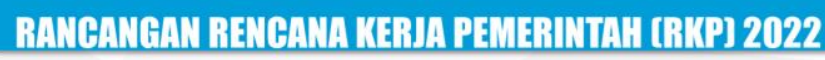

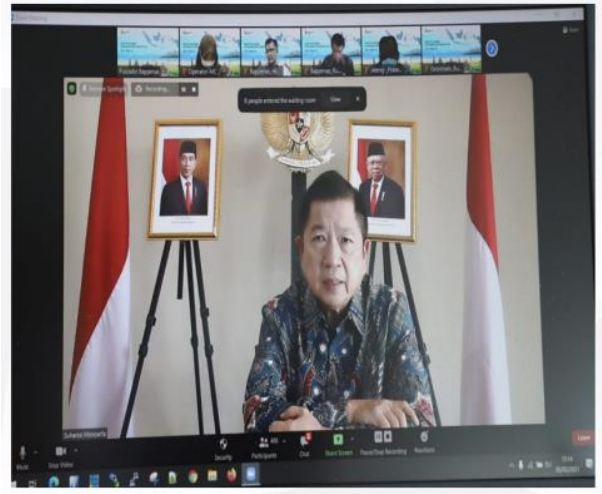

Menteri PPN/Bappenas :

"Dengan pertimbangan kondisi makro dan fiskal pada 2022, maka kata kunci dalam RKP pada 2022 diarahkan pada empat hal, yaitu KEMISKINAN, LAPANGAN KERJA, USAHA MENENGAH, KECIL DAN MIKRO (UMKM), serta INDUSTRI. INVESTASI DAN EKSPOR akan menjadi kunci pemulihan pada 2022, dengan pertumbuhan produk domestik bruto antara 5,4-6,0 persen secara year on year.

Dengan prediksi perekonomian dapat relatif bebas dari tekanan pandemi Covid-19, TAHUN 2022

MERUPAKAN TAHUN KUNCI BAGI INDONESIA UNTUK MELAKUKAN PEMULIHAN DAN AKSELERASI PERTUMBUHAN EKONOMI".

Sumber: Kementerian PPN/Bappenas

Dialog Pra Rakorgub dalam rangka tahapan penyusunan RKP 2022 yang diselenggarakan secara virtual oleh Kementerian PPN/Bappenas (Jum'at, 5 Februari 2021).

Proceedings homepage: https://conferenceproceedings.ump.ac.id/index.php/pspfs/issue/view/9 


\section{ARIULW PBESIDENBI}

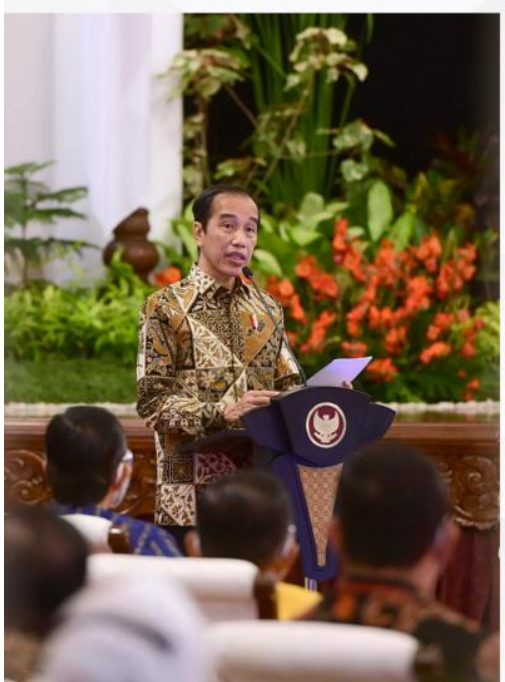

\section{PROGRAM PADAT KARYA}

ARAHAN PRESIDEN RI PADA PEMBUKAAN MUNAS ASOSIASI PEMERINTAH KOTA (APEKSI) SELURUH INDONESIA (KAMIS, 11 FEBRUARI 2021)

1. Perbanyak program padat karya, agar bisa memperkuat daya beli masyarakat, meningkatkan konsumsi masyarakat.

2. Satu-satunya penggerak perekonomian masyarakat saat ini adalah belanja pemerintah, yakni belanja APBN dan APBD.

3. Masyarakat di daerah harus diberikan penghasilan dan pekerjaan seluas-luasnya.

4. Program padat karya juga dilakukan pemerintah pusat di semua kementerian yang ada.

\section{PROGRAM KERJA KEMENTERIAN PERTANIAN 2022}

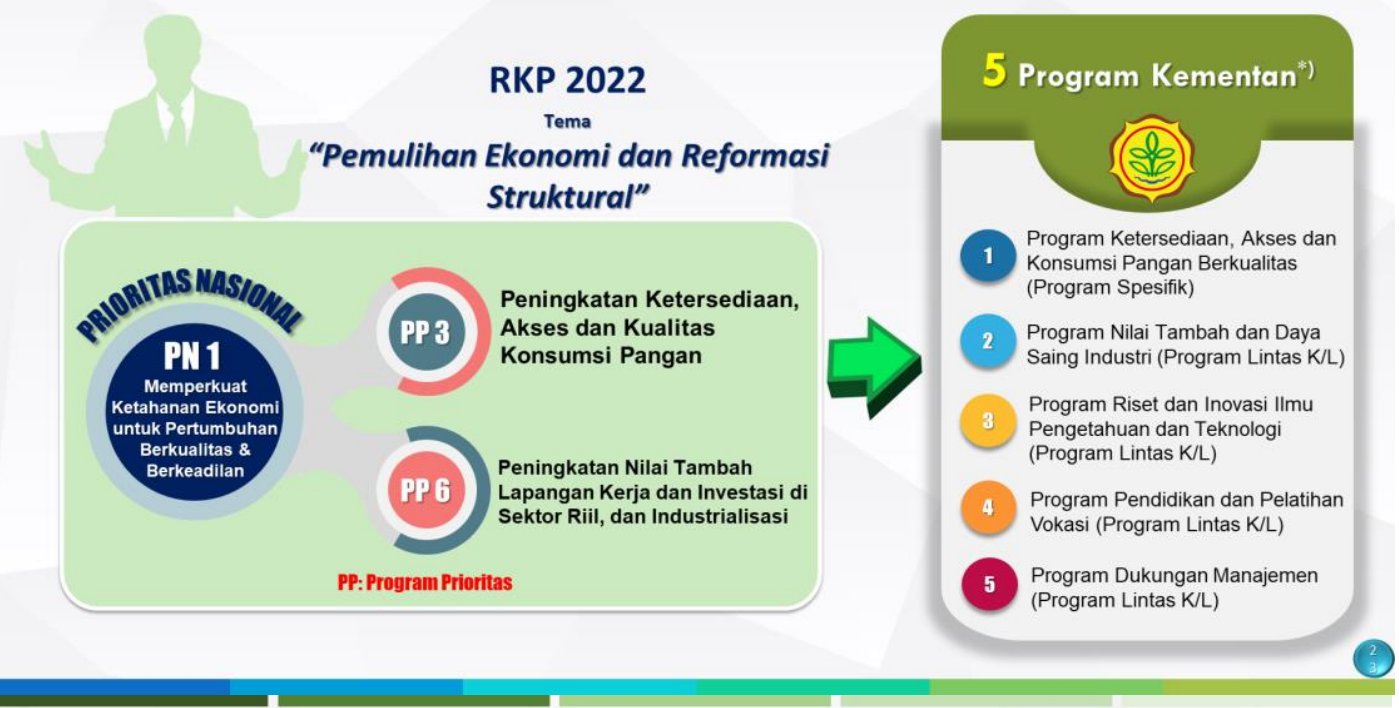

\section{PEMBANGUNAN PERTAMIAN MAJU, MANDIRI, DAN MODERN}

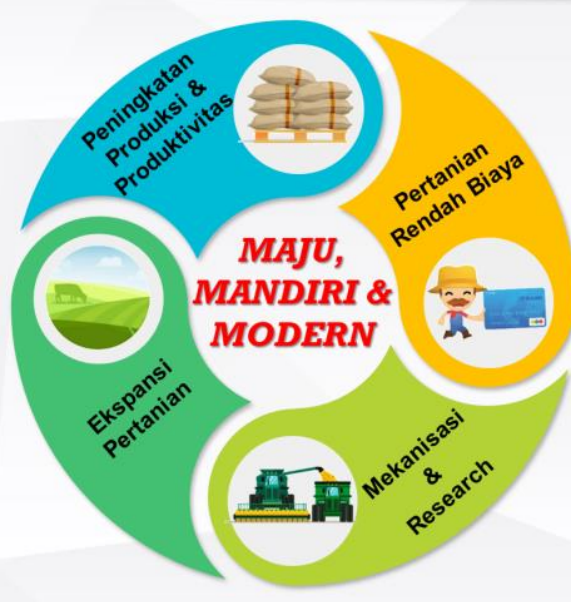

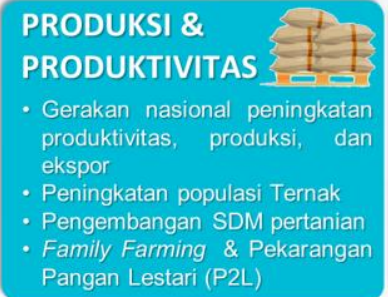

\section{MEKANISASI}

\& RESEARCH

- Pengembangan dan

penerapan mekanisasi

pertanian (pra dan pasca

panen)

- Akselerasi pemanfaatan

inovasi teknologi

\section{PERTANIAN}

RENDAH BIAYA $\overline{\text { a }}$

- Fasilitasi pembiayaan pertanian (KUR bunga rendah)

- Pengembangan kawasan berbasis korporasi

- Bantuan/subsidi pertanian tepat sasaran

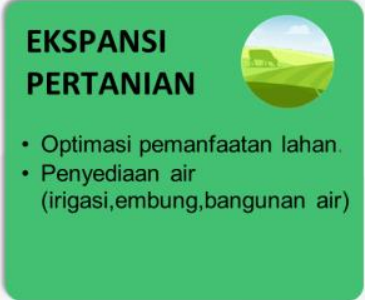




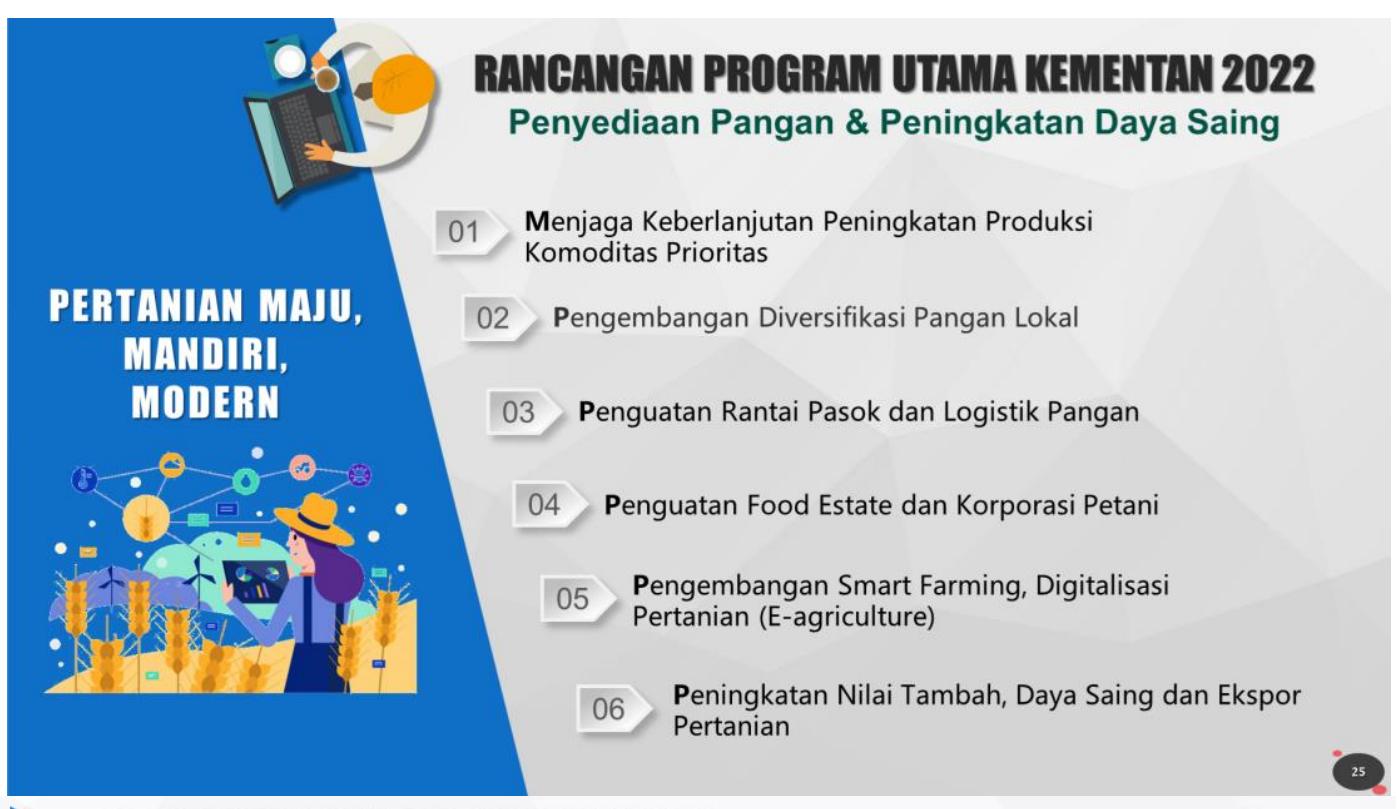

\section{KOMODITAS UNGGULAN PERTANIAN}
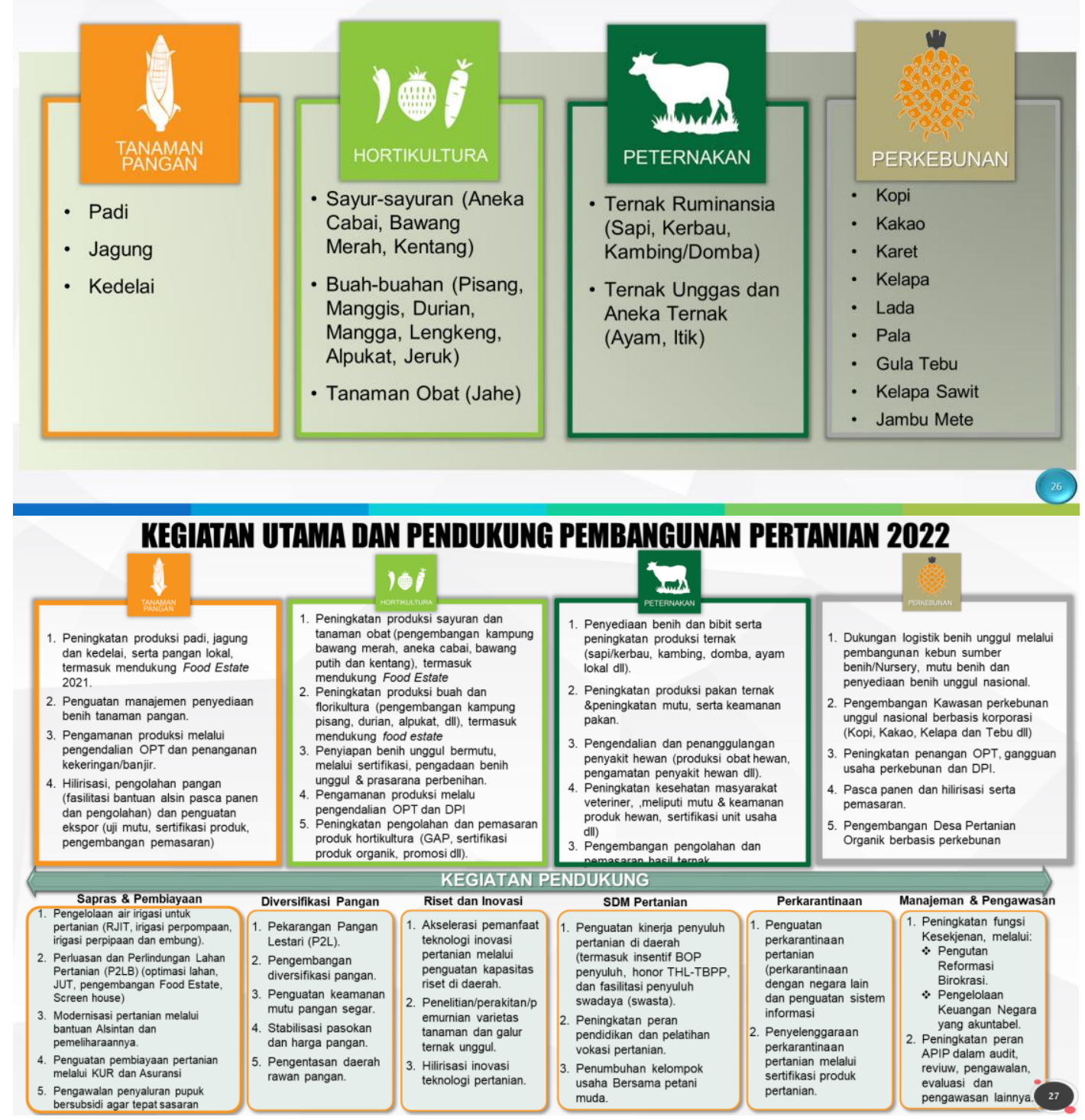

Proceedings homepage: https://conferenceproceedings.ump.ac.id/index.php/pspfs/issue/view/9 


\section{TARGET PRODUKSI KOMODITAS UTAMA 2022}

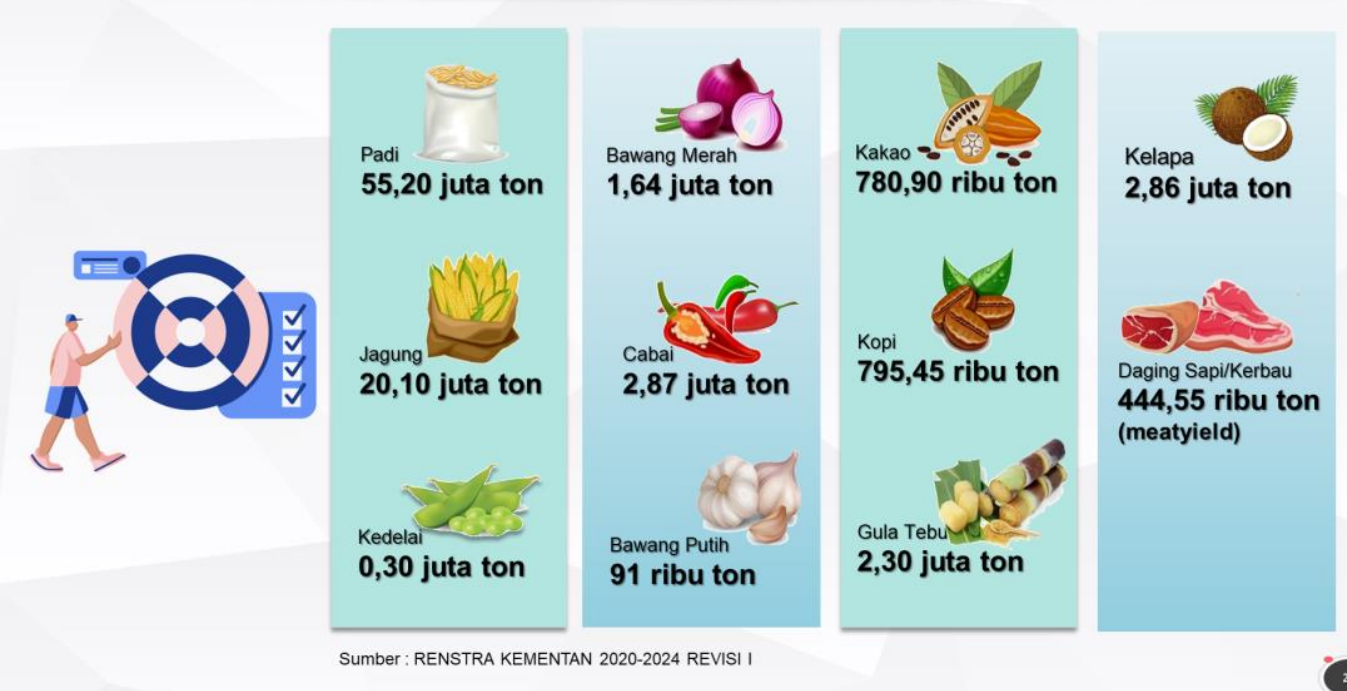

\section{KONSEP PENGEMBANGAN KAWASAN FOODESTATE BERBASIS KORPORASIPETANI}

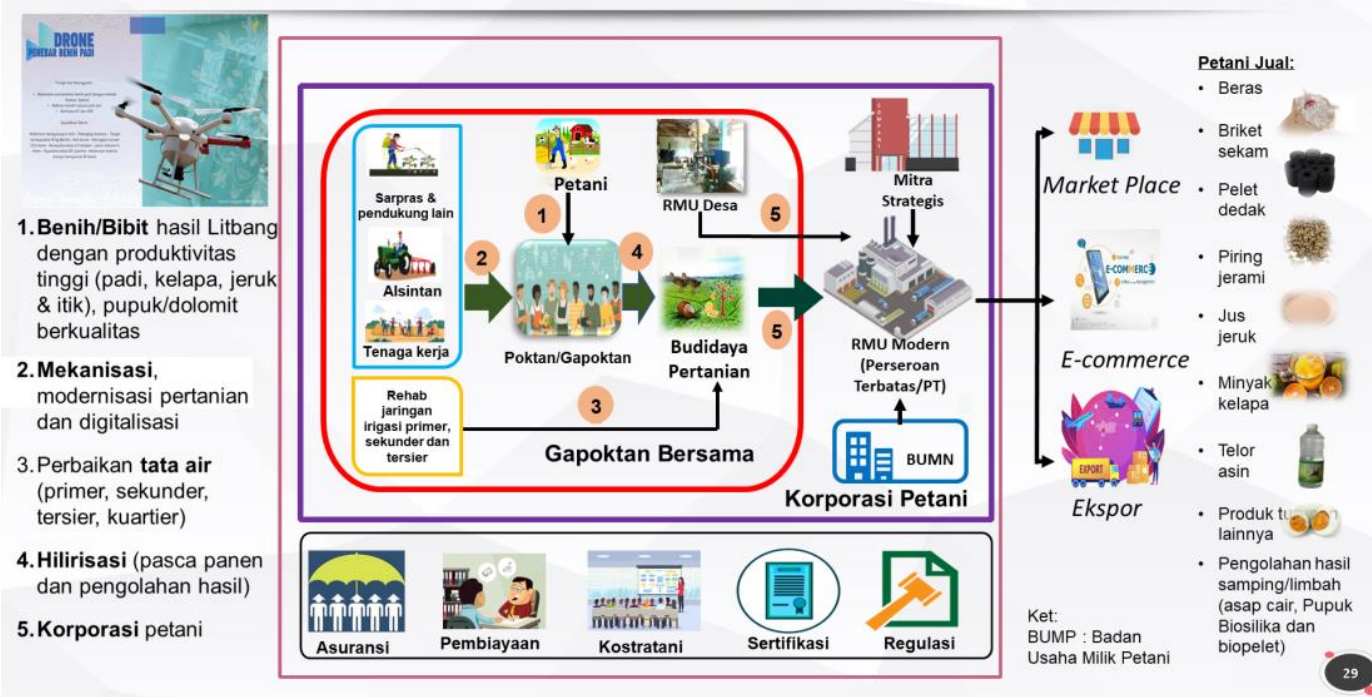

SINERGI PROGRAM DAN ANGGARAN MEWUJUDKAN KETAHANAN PANGAN
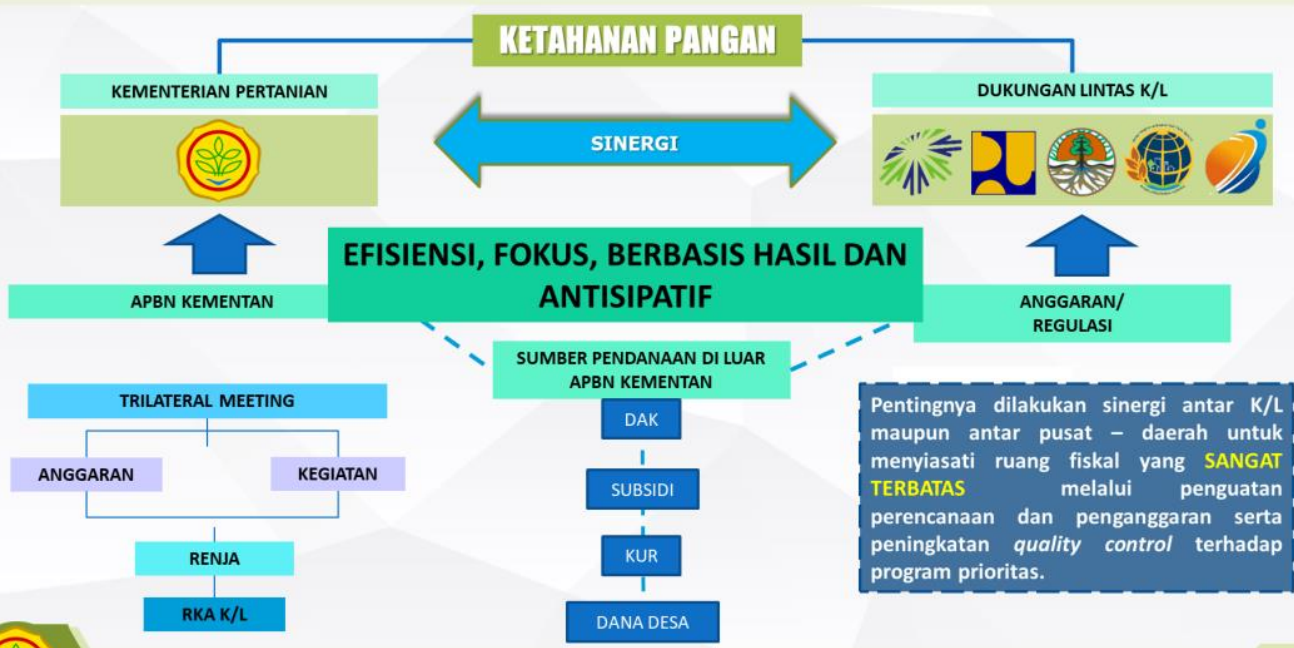

Kementerian Pertanian 

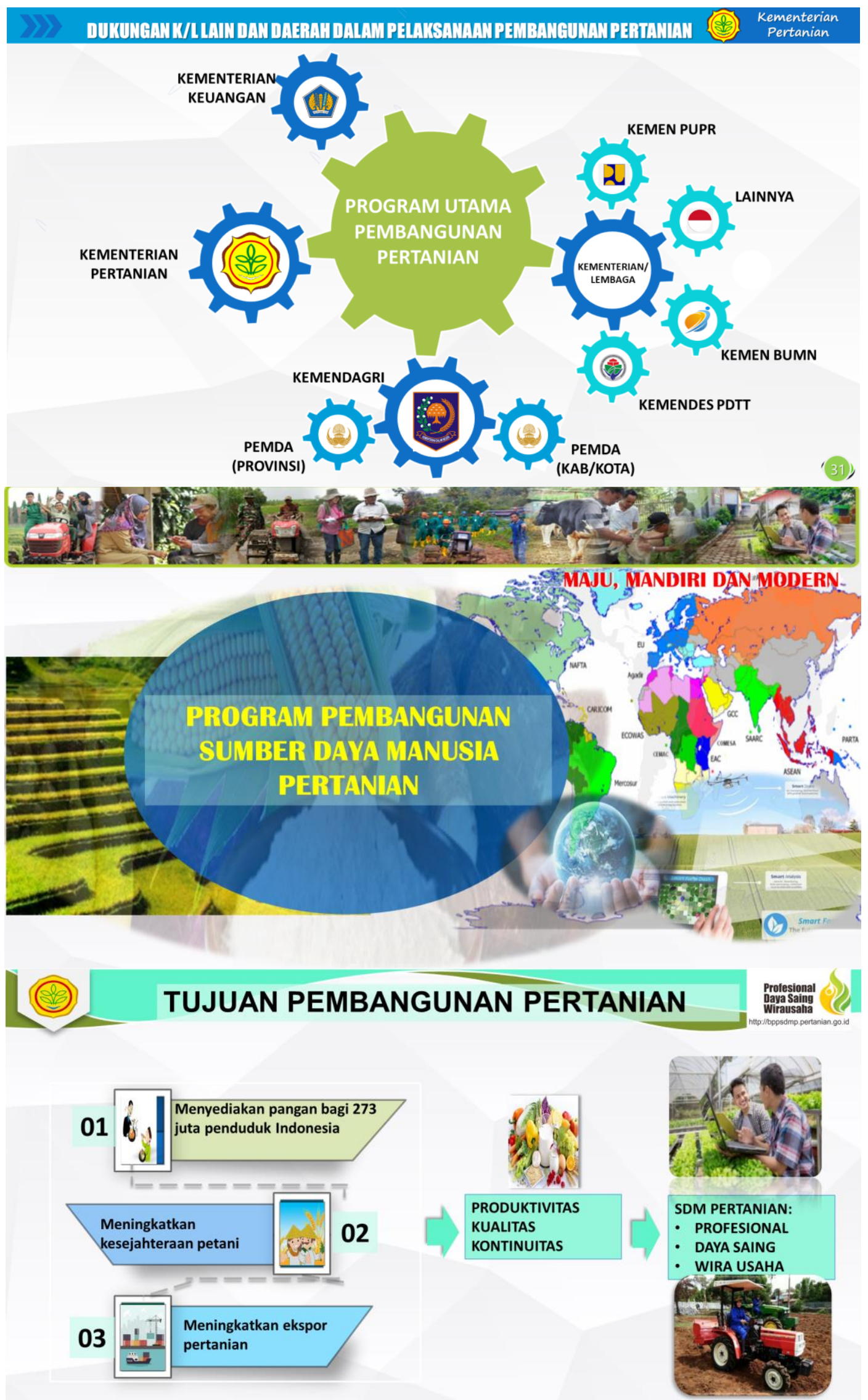


\section{PETANI BERDASARKAN UMUR (KIRI) DAN TINGKAT PENDIDIKAN (KANAN)}

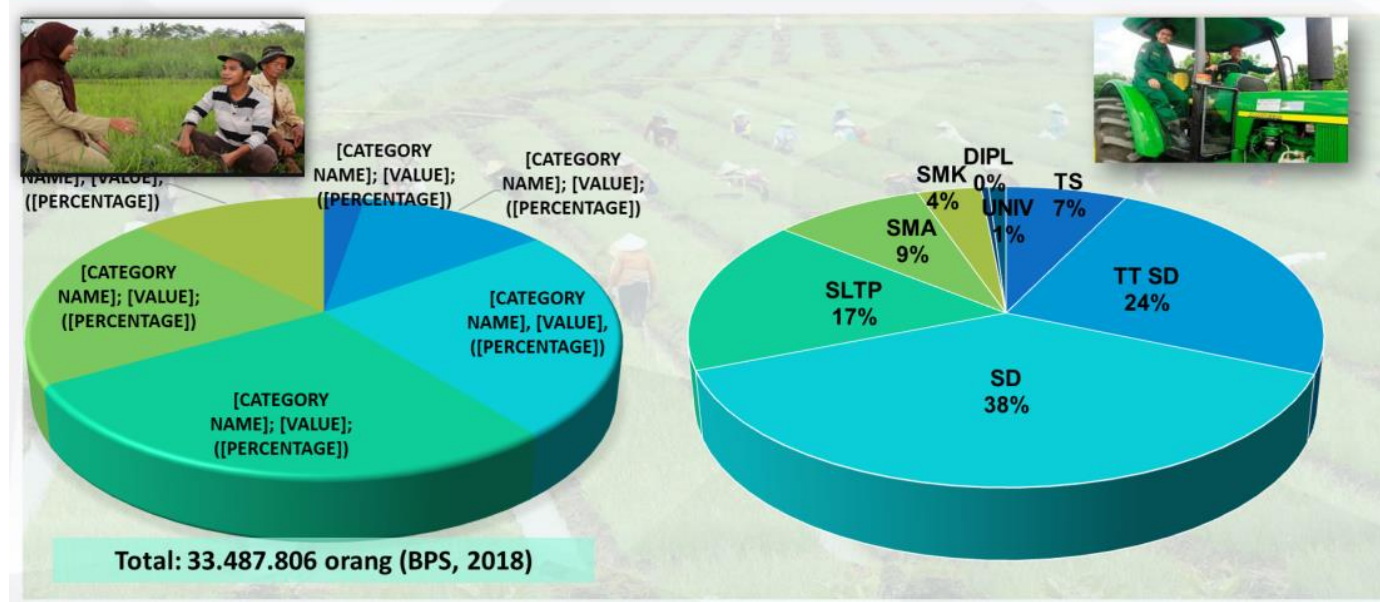

\section{PROGRAM AKSI}

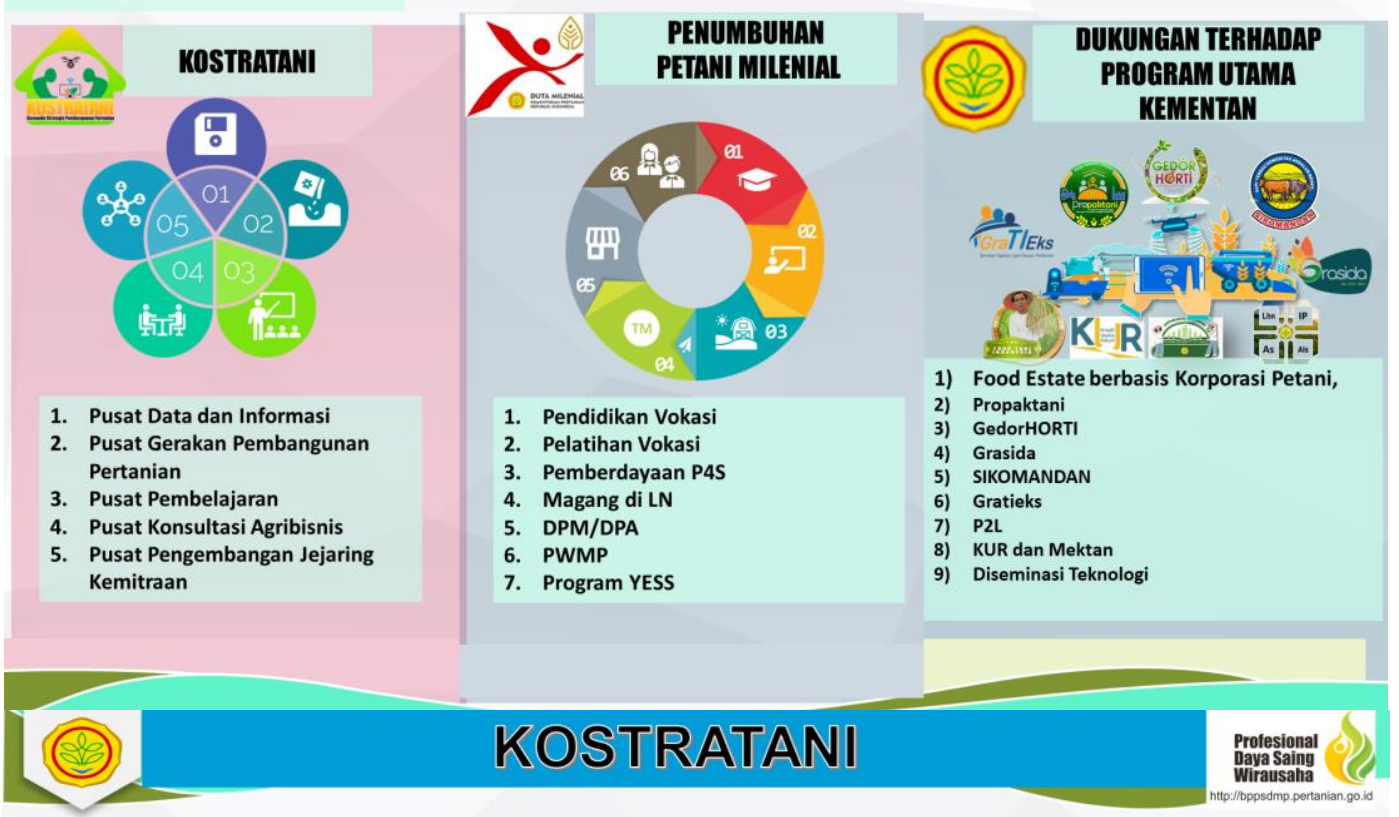

Pengertian: Pusat kegiatan pembangunan pertanian tingkat kecamatan, yang merupakan optimalisasi tugas, fungsi dan peran Balai Penyuluhan Pertanian (BPP) dengan memanfaatkan IT dalam mewujudkan kedaulatan pangan nasional.

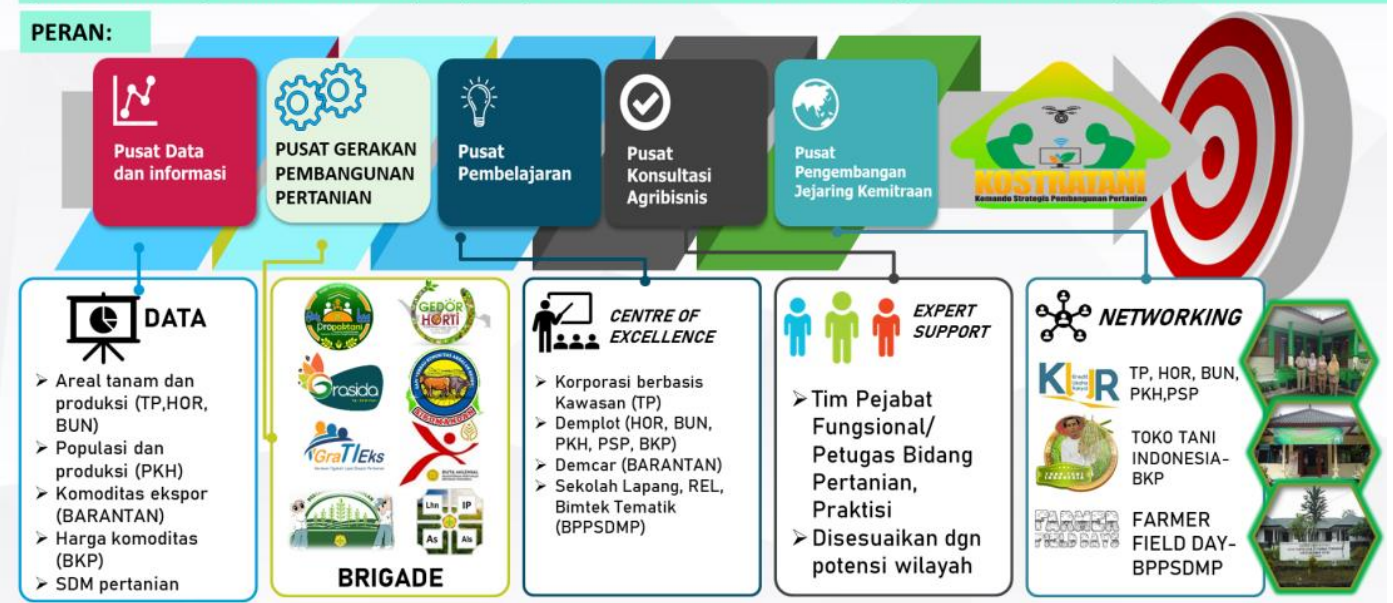



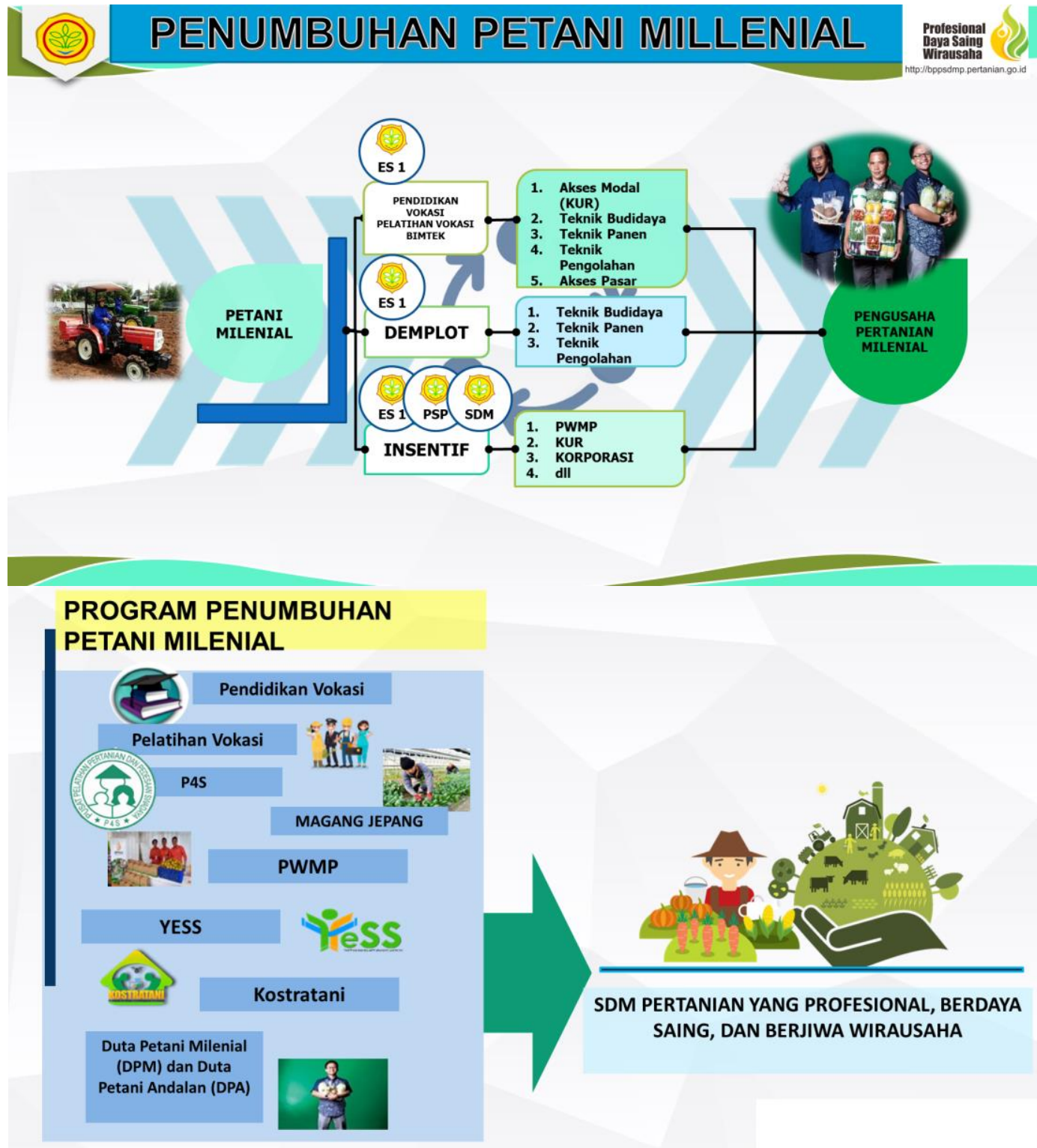

\section{KIPRAH DUTA PETANI MLLENAL DALAM PEMBANGONAN PERTANIAN}

\section{B Bisnis}

Tiga Ton Cokelat Organik Olahan Diekspor ke Qatar

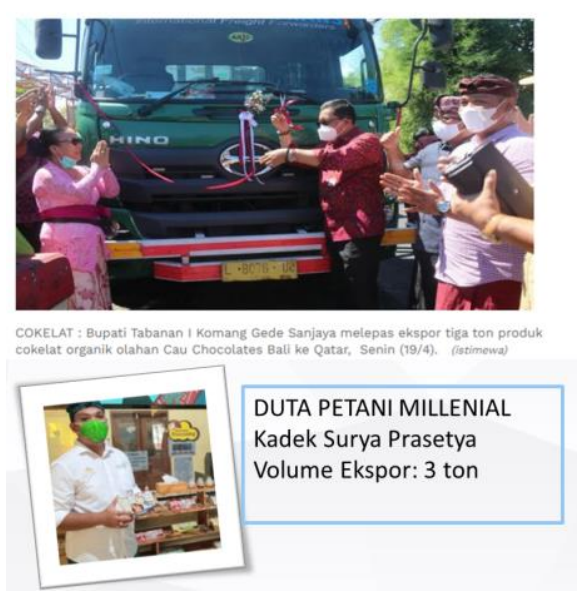

Riza Azyumarridha Azra Tembuskan Mocaf ke Amerika dan Eropa

18 Ju 2020, 1118 wis Eator: Cestio

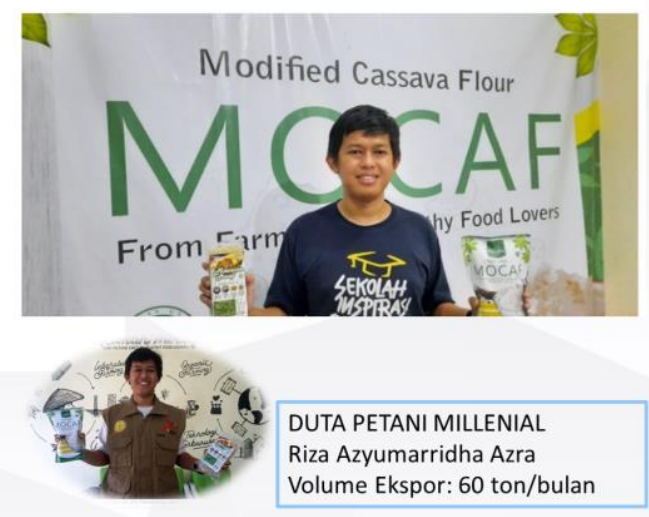




\section{KIPRAH DUTA PETANI MILLENIAL/ANDALAN DALAM PEMBANGUNAN PERTANIAN}

\section{Duta Petani Andalan Terus Merambah Pasar Ekspor Baby Buncis Kenya}

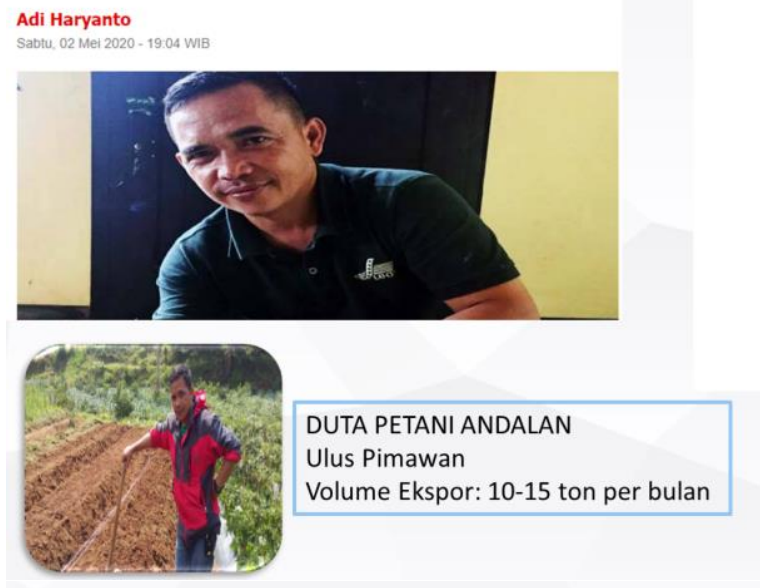

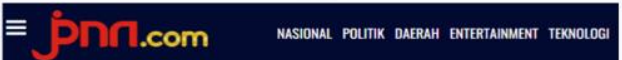

Hendrika Fauzi, Petani Milenial di Aceh yang Mengekspor Kopi Sampai ke Mancanegara
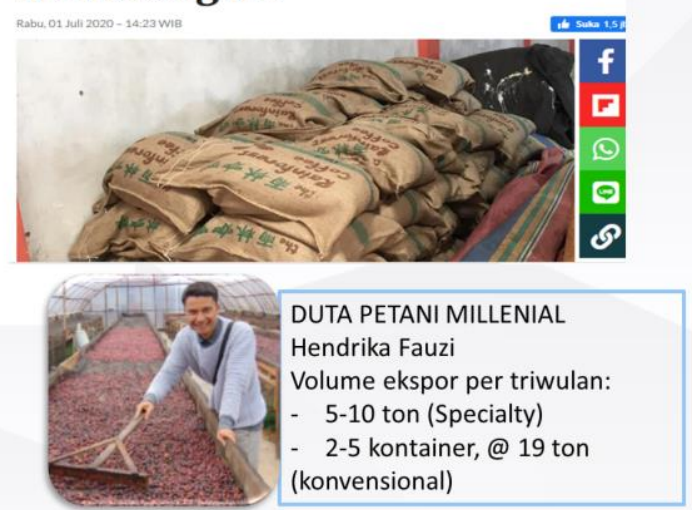

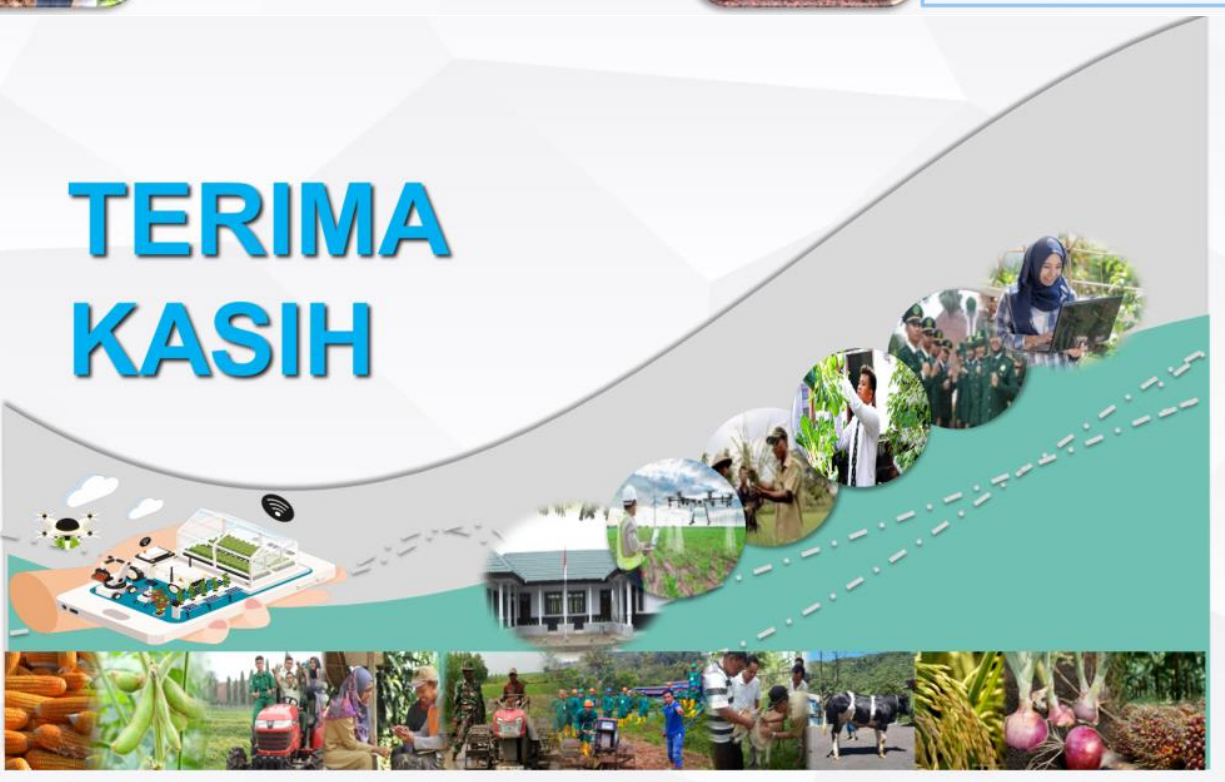

